\title{
Evolving industrial land policy in the developmental state
}

\author{
An-Ting Cheng ${ }^{1 *}$ \\ ${ }^{1}$ University of Taipei, Department of Urban Development, Taipei, Taiwan
}

\begin{abstract}
As a developmental state, Taiwan had a unique institutional system managing industrial land development, which brought rapid economic growth before 1990. But the system gradually initiated conflicts and slowed down industrial development speed, which moved into a period when industrial, environmental and social sectors distrusted and impeded each other. Taiwan's government commenced with an institutional transformation and adjusted central government's position to improve sustainability. A new spatial planning structure was built as a departmental negotiation platform in 2016; and the economic authority raised its policy document 'Industrial Land Policy White Papers' in correspondence to bridge the connections vertically and horizontally. This article analyzes the development of Taiwan's industrial land use policy after the 1960s and argues that the policy has been affected as the change of society. The research therefore concludes three stages during the period from the perspective of historical institutionalism, and argues the current stage which resulted from the introduction of National Spatial Plan may lead to a more sustainable industrial use policy. The departmental policy document, Industrial Land Policy White Paper, constructs the new power structure which reveals the institutional legacy of departmental state strategy. Meanwhile, as a forerunner, Taiwan's experience could provide an example for younger developmental states in easing the conflicts in democratization and industrial development.
\end{abstract}

Keywords: developmental state, industrial land policy, spatial plan, institutionalism.

\section{Introduction}

In the late 20th century, Taiwan's economy improved rapidly, since Taiwan adopted a developmental state strategy as its economic model after World War Two. The government concentrated most resources on industrial development and relatively ignored social and environmental departments. Thus the application faced more and more challenges in the changing society, and gradually led to an unsustainable situation [1]. In this article, unsustainable land use conflicts will be discussed with land use policy, and an explanation will be offered on how Taiwan reduced conflicts through institutional changes.

\footnotetext{
* Corresponding author: acheng@utaipei.edu.tw
} 
The highlighted issue is: how a developmental state strategy country improves the balance between economic and other departments and achieves sustainability, which contains continuously industrial development and efficient land use. As a result, to develop Designated Industrial Parks in cooperation with spatial plan was the main target of institutional adjustments.

This article intends to connect the discussion on the development of Taiwan's industrial policy with the specific problems encountered in managing its land use. It will trace the logic of industrial land supply from the historical context to the current challenges briefly, but focus on the relationship changes between economic development model and the guidance from spatial plans. Finally, it will introduce the institutional adjustments which made developmental state country become more balanced between economic and environment, and discuss the institutional legacy.

\section{Literature review}

\subsection{Developmental state strategy and institutionalism}

Johnson [2] proposed the concept of developmental state in 1982, he thought that the government used international trade and its industrial department to lead the economy, resulting in rapid growth in post-war era. The pattern of development in other East Asia countries was also influenced by Japan, including Taiwan, South Korea and Singapore. Studying East Asia developmental states, Wade, R. [3] pointed out the positive government and strategic industrial policies as the important factors rapidly promoting economic growth; these two factors are oriented strategically as market-leading, not as following. Accordingly, the developmental state was concluded as signifying high intervention in economic development; Wang, S. [4] even clearly pointed out the three main features of developmental states: First, the government strongly intervenes in the market and establishes the dedicated agencies to formulate development strategies and lead the economic development. Second, it adopts flexible industrial policies to support the strategic industries with various subsidies and safeguards. Third, it implements clear social policies, carries out land reform, and maintains social and economic equality to prevent serious political conflicts.

In the words of institutionalism, scholars place special emphasis on the role institutions play in structuring behavior [5-6], and the most common definition for institutions is rules. Steinmo [7] believes the rules enabled different political strategies in different countries and ultimately shaped the different policy outcomes.

\section{Methods}

\subsection{Historical institutionalism and case study approach}

Author adopts historical institutionalism perspective and applies it to the development of industrial land use policy in Taiwan as a case study. The case study approach is an ideal method for exploratory and explanatory research which needs to take a broad range of factors into account whilst the institutional approach offers the possibility of looking at the development of industrial land use policy as the continuing change of social circumstance. 


\subsection{The challenges to industrial land policy}

In reviewing the number of Designated Industrial Parks since 1960s (see Figure 1), Taiwan's government developed the most industrial parks in the 1970s and made efforts to develop heavy chemical industry at the same time. The weaker growth of the industrial park development system after the 1970s reflected the transformation of the modern industrial structure, industrial policy and the government's attitude. The authority of economic plans in Taiwan proposed a review of industrial park development in 1981. The review pointed that the development of industrial parks was usually indicated by a single project under the economic plan, as a result, there was a lack of comprehensive consideration of the surrounding area, which caused industrial parks' incompatibility with spatial planning [8].

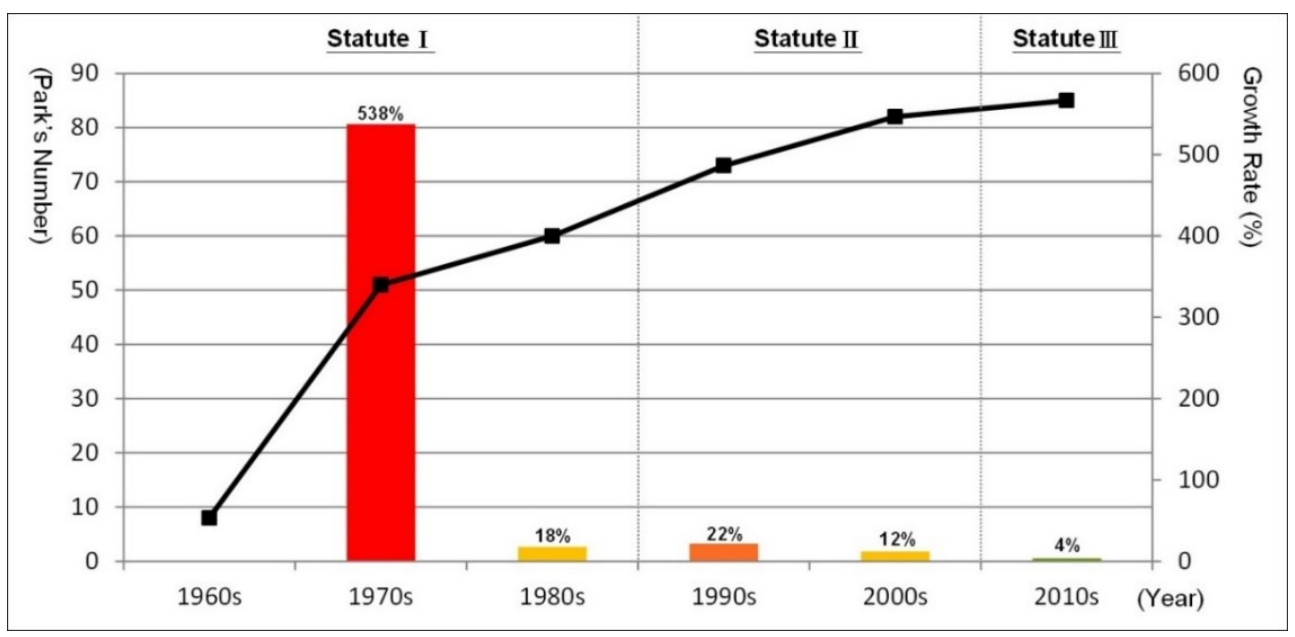

Fig. 1. The growth of Designated Industrial Parks 1960s-2010s.

Remark 1: Designated industrial parks in Figure 1 only includes central government; the local government and private parks are excluded.

Remark 2: Statute 1 enforced in 1960 and abrogated in 1991; Statute 2 enforced in 1990 and abrogated in 2010; Statute 3 enforced in 2010.

Source: The Development of Industrial Land in Taiwan [9].

\section{Results}

\subsection{Institutional adjustments towards sustainability}

The lack of coordination between industrial land policy and spatial planning inevitably led Taiwan into an unsustainable situation. Though numerous scholars believed that Taiwan's spatial planning had transferred from earlier "blueprint planning" to "Neo-liberalism" [1012], it does not mean that the state's functional role disappeared. With globalization, the ways and functions of state engagements go deeper into local connections over the world instead, which means Neo-liberalism intensifies the developmental state strategy [12].

\subsection{Rebuild land use order through spatial planning}

National Spatial Plan in Taiwan was based on the "Spatial Planning Act" promulgated on May $1^{\text {st }}, 2016$. The new Act has not only incorporated departmental spatial plans, but also 
made a major change in the spatial planning framework [13]. However, the planning logic did not completely detach from the top-down approach and economic developmentorientation of developmental state due to the shortage of civil organizations' supports and their mass mobilization [14]. It divides land into four functional divisions: Environmental conservation zone, Marine resource zone, Agricultural development zone and Urban-rural development zone (as Figure 2.). To ensure land use policy stability, functional zones will only be reviewed every 10 years, that is to say, zoning conversion would be more difficult and make industrial land development less flexible than before [15].

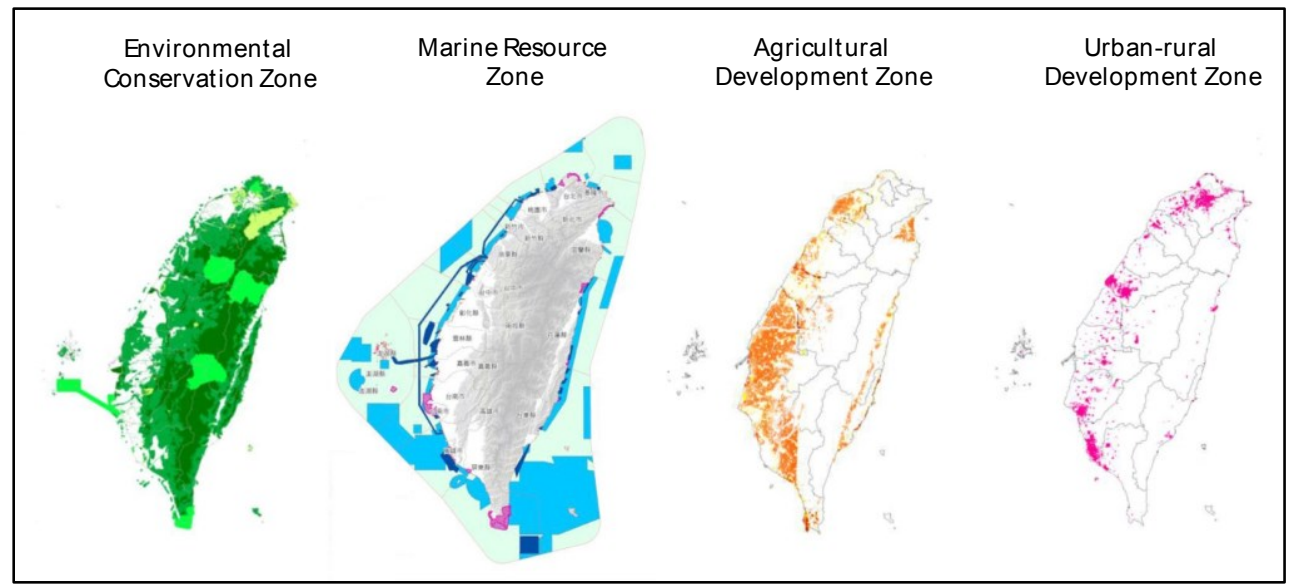

Fig. 2. Functional zones distribution schematic diagram.

Source: Edits from the slides of National Spatial Plan (draft in July 2017).

\subsection{Response from the Industry Sector}

In order to encounter the institutional change of spatial policy, the Ministry of Economic Affairs takes the responsibility of industrial land planning to prevent industrial development be limited by the frame of national spatial plan, and elaborate the policy position of industrial land by "Industrial Land Policy White Papers" in February 2019 to influence the national spatial plan and achieve effective negotiations among departments.

It is the first time for economic planning authority to communicate industrial land policies with society by white paper, some basic instructions about industrial land development issues are included. The White Paper is positioned at departmental level based on the industrial development's viewpoint, however it had a significant success in spatial planning process. Most of the goals of this white paper in terms of the amounts and location of industrial land in the next five years, were applied to the Spatial Plan.

\section{Discussion}

\subsection{Institutional Legacy of Industrial Land Policy}

Through reviewing the development of industrial land use policy in Taiwan, there are various models applied in each period (Fig. 3). Before 1980s, developmental state strategy supported economy to hold the dominance and led environmental and social departments via economic plans.

Afterwards, with rising public awareness and a more mature institutional environment, the environmental and social departments became more active and influential from the 1990s 
to the 2010s. Thus the dominance in this period was fuzzy and some conflicts were created, while the economic and social departments almost had no communication.

As Taiwan's government has noticed the problem arising from the disconnection of industrial development and spatial planning, the National Spatial Plan was designed as a platform to agglomerate consensus among departments. The economic authority started to enhance the communication with society and released partial authority to local governments, changing the past central government dominated model. The planning system turned to having every department submit their departmental spatial plan, and then negotiate at the National Spatial Planning platform in order to achieve a balance among departments.
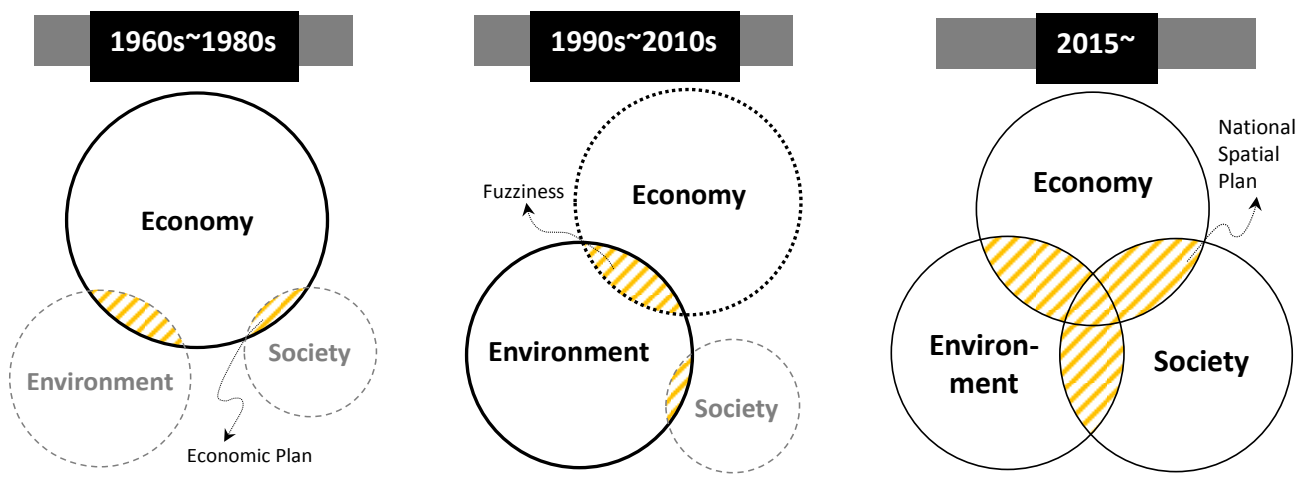

Fig. 3. The relationships of development models

\section{Conclusion}

Three main issues can be concluded regarding industrial development in modern Taiwan. First, the industrial policy needs to be transformed to reduce development resistance. The central government has lost the power to lead national industrial development and promulgated the Industrial Land Policy White Paper to bridge the connections vertically and horizontally. In the future, the central government will only focus on forward-looking industrial development and empower local governments to plan their industrial development under guidance from the economic authority. The outcome of the power structure conversion reveals the institutional legacy of departmental state strategy.

Second, how the government can reduce the conflicts between urbanization and industrial development remains an issue; it stems from the imbalance of the economic, environmental and social departments. In this respect, Taiwan builds a platform through institutional design to provide for inter-departmental negotiations.

Third, the future role of the Taiwan government plays in industrial development has yet to be determined. Fortunately, the officials from the economic authority are going to revise the related regulations in the third industrial statute. Therefore, the following institutional development is worth expecting and observing. In addition, Taiwan's experience could provide other developmental states as a reference for early responses to the future transformations of the industrial and social environments.

\section{Acknowledgments}

This research was funded by the Ministry of Science and Technology, Taiwan, R.O.C., grant number MOST 104-2410-H-214-017. 


\section{References}

1. A.T. Cheng, Issues of Industrial Land in Taiwan, Taiwan Real Estate Yearbook (Chengchi University, Taipei, 2019)

2. C. Johnson, MITI and the Japanese Miracles: The Growth of Industrial Policy, 19251975 (Stanford University Press, Palo Alto, US, 1982)

3. R. Wade, Review of International Political Economy, 10(4), 621-644 (2003). https://doi.org/10.1080/09692290310001601902

4. S.J. Wang, 後威權時期臺灣國家社會關係一國家能力與社會自主性 [Postauthoritarian Period National Social Relations in Taiwan-State Capacity and Social Autonomy], PhD Thesis (National Chengchi University, Taipei, 2004)

5. H. Farrell, The shared challenges of institutional theories: Rational choice, historical institutionalism, and sociological institutionalism, in Knowledge and institutions, 2344 (Springer, Cham, 2018). https://doi.org/10.1007/978-3-319-75328-7_2

6. A. Sorensen, New institutionalism and planning theory. The Routledge Handbook of Planning Theory (Routledge, New York, 2017)

7. S. Steinmo, Historical institutionalism, in Approaches and methodologies in the social sciences: A Pluralist Perspective, 118-138 (Cambridge University Press, New York, 2008). https://doi.org/10.1017/CBO9780511801938.008

8. Sh.-Y. Kao, Taiwan Industrial History (Wu-Nan, Taipei, 2016)

9. A.T. Cheng, The Development of Industrial Land in Taiwan, Paper presented at the $50^{\text {th }}$ Anniversary of the International Center for Land Policy Studies and Training, 25 May 2018, Taiwan (2018)

10. C. Wang, Moving toward Neoliberalization? The Restructuring of the Developmental State and Spatial Planning in Taiwan, in Locating Neoliberalism in East Asia:

Neoliberalizing Spaces in Developmental States, 167-195 (Wiley-Blackwell, Oxford, UK, 2012)

11. Y.J. Lee, I.C. Lan, H.H. Juang, Journal of Geographical Sciences, 40, 69-97 (2005)

12. T.L. Chou, City and Plan, 28(4), 461-494 (2001)

13. Y.J. Lee, Economic Outlook Bimonthly, 170, 48-52 (2017). https://doi.org/10.30071/EOB

14. W.J. Huang, Planning Practice \& Research, 34(1), 120-130 (2019). https://doi.org/10.1080/02697459.2018.1523289

15. J.R. Chiou, Taiwan Economic Research Monthly, 41(9), 89-96 (2018). https://doi.org/10.29656/TERM.201809.0012 